\title{
IMPROVISED AND VALIDATED OF TWO SPECTROPHOTOMETRY METHOD FOR PARALEL ASSAY OF GUAIPHENESIN, ACETAMINOPHEN AND CTM COMBINE IN SYRUP
}

\author{
Muchlisyam Bachri, "Masfria and Yade metri Permata \\ Department of Pharmaceutical Chemistry, Faculty of Pharmacy, Universitas Sumatera Utara, \\ Kampus USU, Padang Bulan, Medan, 20155. Indonesia. \\ *E-mail: muchlisyam@usu.ac.id
}

\begin{abstract}
These studies aimed was too improvised and validated the absorption of the ratio method and mean centralization of the ratio spectrum method for determination to estimate the combination of guaiphenesin, acetaminophen, and CTM in the local syrup product. The preparation of guaiphenesin, acetaminophen, and CTM uses methanol-water as a solvent. Determination with the ratio absorption spectrum method on $\lambda 235.8 \mathrm{~nm}$, and Mean centralization of ratio spectrum at the second ratio and has a retrogression equation for guaiphenesin at $274 \mathrm{~nm}$ is $\mathrm{y}=0.60171 \mathrm{X}+$ 0.057918 , acetaminophen at $269 \mathrm{~nm}$ is $\mathrm{y}=0.73291 \mathrm{X}+0.00436$, and CTM at $257 \mathrm{~nm}$ is $\mathrm{y}=0.08347 \mathrm{X}-0.025702$. The absorption of the ratio method has an intersection point at $235.8 \mathrm{~nm}$. The guaiphenesin level is $(99.16 \pm 0.014)$ $\%$, acetaminophen at $(99.77 \pm 0.014) \%$, and CTM at $(99.71 \pm 0.014) \%$. The Mean centralization of ratio spectrum method has a level for guaiphenesin at $274 \mathrm{~nm}$ is $(100.95 \pm 0.7761) \%$, acetaminophen at $269 \mathrm{~nm}$ is $(100.76 \pm 1.4152))$ $\%$ and CTM at $257 \mathrm{~nm}$ is $(101.43 \pm 0.5327) \%$. The measurements of all validation parameters have an excellent result, indicate that the three components of the drug meet the requirements of the ICH guidelines. The absorption of the ratio method and the method of mean centralization ratio spectra can use to analyze for the syrup of product local mixture. The level has been suitable to the $27^{\text {th }}$ edition of the United States Pharmacopeia.

Keywords: Absorption of Ratio Methods, Mean Centralization of Ratio Spectrum, Validation.
\end{abstract}

C RASĀYAN. All rights reserved

\section{INTRODUCTION}

Nowadays, the combination of the guaiphenesin (GUA), acetaminophen (ACET), and CTM is often used as an active ingredient to relieve symptoms of coughs and colds, is often used as an active substance to relieve symptoms of runny nose. ${ }^{1,2}$

Guaiphenesin or glyceryl guaiacolate has an expectorant and antitussive effect by reducing the viscosity of mucous secretions, surface tension, mucus dilution and removing secretions in the respiratory tract, besides that it is also used to help clear mucus or phlegm from the chest. This drug is available without a prescription and is often combined for cold and cough symptoms ${ }^{2,3}$. Acetaminophen or N-Acetyl-p-aminophenol is a drug ingredient in the form of over-the-counter drugs that can combine with ingredients that treat allergies, coughs, colds, influenzas such as guaiphenesin and CTM. This compound is included in the class of drugs with analgesic and antipyretic effects. This analgesic drug reduces pain by reducing the production of prostaglandins in the body due to tissue damage or infection, which results in inflammation, fever, and pain., 3

CTM is a derivative of alkyl-amine, which includes first-generation antihistamines. This drug works by inhibiting the action of histamine, so it is used in the prevention of allergies such as rhinitis and urticaria due to excessive histamine production. Besides that, it is also used to relieve nasal congestion, runny nose, watery eyes and painful swallowing, as well as coughing, sneezing and fever., ${ }^{4}$

The ultraviolet spectrophotometric method can be used to determine the levels of single form from GUA, ACET and CTM. That's GUA in an acid solution at $\lambda 273 \mathrm{~nm}$, ACET in an alkaline solution at $\lambda 257 \mathrm{~nm}$, and CTM in an alkaline solution at $\lambda 262 \mathrm{~nm}^{6}$

Rasayan J. Chem., 13(4), 2256-2265(2020)

http://dx.doi.org/10.31788/ RJC.2020.1345790 
RASĀYAN J. Chem.

Vol. 13 | No. 4 |2256-2265| October - December | 2020

In recent years, the use of spectrophotometric methods has been developed, with the application of mathematical software on the computer to the simultaneous assay of a drug mixture directly, even with adjacent wavelengths. The development of separability using analytical instruments equipped with microcomputers with the software. ${ }^{7,8}$

Afkhami and Bahram (2005) have published the simultaneous assay of drug mixtures containing two or three components using the Mean Centralization of Ratio Spectra spectrophotometric method, without separating steps first derivatization in binary mix analysis. Some researchers have used the MCR method to determine the mixtures of drugs such as amlodipine, aliskiren, and hydrochlorothiazide, a combination of thiomersal, lidocaine, and phenylephrine drugs, a mixture of diclofenac sodium and sodium pantoprazole, isopropamide iodide, trifluoperazine hydrochloride and trifluoperazine oxidative degradation, and metformin and glibenclamide mixture. ${ }^{8-13}$

The absorption of the ratio is a spectrophotometric method that can be used to determine the amount of drug in the form of a mixture. This method uses measurement absorption at two wavelengths, which is the intersection point and the other as an absorption maximum of pharmaceutical preparations containing two or three mixtures of active substances of different drugs gives good results and accurate. ${ }^{14-17}$

The goal of this study is to evaluate simultaneously of GUA, ACET, and CTM without any treatment in the preparation of syrup separation method of absorption of ratio method and mean centralization of the ratio spectrum method.

\section{Material}

\section{EXPERIMENTAL}

Pharmaceutical grades of the GUA, ACET, and CTM were from the National Agency of Drug and Food Control of the Republic of Indonesia, Methanol p.a E.Merck from PT Rudang Jaya, Medan Indonesia, UV Spectrophotometer(Shimadzu 1800) software UV-Probe 2.42.

\section{Prepare a Stock Solution}

Weighed carefully $25.1 \mathrm{mg}$ GUA, $25.5 \mathrm{mg}$ ACET, and $25.1 \mathrm{mg} \mathrm{CTM}$, then transferred to three $50 \mathrm{ml}$ graduated flasks, then added the methanol-water mixture (1:4) to mark the line. Each pipette of $5 \mathrm{ml}$ solution and put into three $25 \mathrm{ml}$ measuring flasks, diluted with methanol-water to the mark of the line to get a stock solution of $101.2 \mu \mathrm{g} / \mathrm{ml} \mathrm{GUA}, 108 \mu \mathrm{g} / \mathrm{ml} \mathrm{ACET}$ and $101.2 \mu \mathrm{g} / \mathrm{ml} \mathrm{CTM} .^{5,6}$

\section{Construction of the Absorption Spectrum}

The stock solution of $9 \mathrm{ml}$ GUA, $1.5 \mathrm{ml} \mathrm{ACET}$, and $7.8 \mathrm{ml}$ of CTM transfer to three-piece of $25 \mathrm{ml}$ measuring flask. Then diluted with methanol solvent: water to the sign-line and shaken until it is homogeneous. So that each solution phis obtained with a concentration of $36.4 \mu \mathrm{g} / \mathrm{ml} \mathrm{GUA}, 6 \mu \mathrm{g} / \mathrm{ml}$ ACET and $31.3 \mu \mathrm{g} / \mathrm{ml} \mathrm{CTM}$ and each is measured uptake at a wavelength of $200-400 \mathrm{~nm} .{ }^{8,9}$

\section{Preparation of Mixed Absorption Spectrum}

Weighted carefully $25.2 \mathrm{mg}$; GUA, $25.1 \mathrm{mg}$ ACET, and $25.2 \mathrm{mg}$. CTM, respectively; transferred to a 25 $\mathrm{ml}$ graduated flask, diluted with methanol: water to the sign-line and stirred until homogenized. Then pipette $1.5 \mathrm{ml}$ of ACET solution; $8.7 \mathrm{ml}$ of GUA; $5.3 \mathrm{ml}$ of CTM solution, respectively, and transferred to $25 \mathrm{ml}$ graduated flask, filled with methanol solvent: distilled water $(1: 4)$ to the sign-line, shaken until homogeneous. Measured absorption at a wavelength of $200-400 \mathrm{~nm} .{ }^{18,19,20}$

\section{Method of Validation \\ Exact Data Test}

An exact test data was carried out by the standard addition method, by making three concentrations of analyte samples with a specific range of $80 \%, 100 \%, 120 \%$ where each treatment was carried out three times. Each variety contains $70 \%$ of the analyte and $30 \%$ of the standard comparison, then analyzed with the same procedure as in the sample concentration. The following is the formula for percent recovery. ${ }^{21,22}$

$$
\text { Percent recovery }=\frac{\mathrm{CF}-\mathrm{CA}}{\mathrm{CA} *} \mathrm{X} 100 \%
$$


RASĀYAN J. Chem.

Vol. 13 | No. 4 |2256-2265| October - December | 2020

Note:

$\mathrm{CF}=$ Number of analytes measured

$\mathrm{CA}=$ Amount of analyte in the sample

$\mathrm{CA}^{\wedge *}=$ Default number added

Nicety

Nicety is expressed as SD or RSD from a series of data. To find RSD using the formula. ${ }^{21,22}$

$$
\mathrm{RSD}=\frac{\mathrm{SD}}{\mathrm{X}} \times 100 \%
$$

Limit of Detection and Limit of Quantification

Limit of Detection (LOD) and Limit of Quantification (LOQ) is obtained based on the absorbance value at the wavelength of the analysis carried out by formula. ${ }^{21,22}$

$$
\begin{aligned}
& \mathrm{SD}=\sqrt{\frac{(\mathrm{Y}-\mathrm{Yi}) 2}{n-2}} \\
& \mathrm{LOD}=\frac{3 \times S D}{\text { slope }} \\
& \mathrm{LOQ}=\frac{10 \times S D}{\text { slope }}
\end{aligned}
$$

Note:

RSD = Relative standard deviation

$\mathrm{SD}=$ Standard deviation

$\mathrm{X} \quad=$ The data have been average

\section{Construction of Calibration Curves in Mean Centralization Of Ratio Spectra (MCR)}

The value of the mean center (MC) or the magnitude of the second ratio spectra, respectively from GUA, ACET, and CTM at the maximum wavelength obtained. Calculated by plot the MC values Vs maximum wavelength of each standard to get the equation of the regression line. ${ }^{23,24}$

\section{Determination of Simultaneous Drug Mixture in Syrup Preparations by Mean Centralization Of Ratio Spectra}

MC measurement of syrup samples in the MCR method was done by adding raw materials for GUA and CTM. Carefully measured $2.5 \mathrm{ml}$ of a solution equivalent to $60 \mathrm{mg}$ of ACET, transfer to a $50 \mathrm{ml}$ flask, and add the solvent to the marked line. Homogeneous with a sonicator for 10 minutes. Filtered, pipette as much as $5 \mathrm{ml}$ into a $25 \mathrm{ml}$ flask and diluted with a solvent to the marked line. Pipette $0.6 \mathrm{ml}$ of sample into a 25 $\mathrm{ml}$ graduated flask, added $7.7 \mathrm{ml}$ of the CTM stock solution, and $8.7 \mathrm{ml}$ of GUA stock solution as an addition. Sufficiently with solvent until the marked line. So the solution would be predicted to contain 31 $\mu \mathrm{g} / \mathrm{ml}$ GUA, $6 \mu \mathrm{g} / \mathrm{ml}$ ACET, and $36 \mu \mathrm{g} \mathrm{ml} \mathrm{CTM}$. Because it was following the standard absorption spectrum of a GUA, ACET, CTM ratio of 36: 6: 31 while the comparison in drug preparations following standard ACET was 1.2: 6: 0.05. Absorption measurements are carried out at a wavelength of $200-400 \mathrm{~nm} .{ }^{8,9}$

\section{Preparation of the Calibration Method for the Absorption of Ratio Methods}

The values from the absorption of ratio in the solution of GUA, ACET and CTM respective are measured at the maximum wavelength, and isoabsorption wavelength obtained. The absorbance is plotted with the concentration, then calculated, the regression line equation will be obtained..$^{23,24}$

\section{Determination of Simultaneous Drug Mixture in Syrup Preparations by Absorption of Ratio Methods}

Pipette $1 \mathrm{ml}$ of syrup and repeated six times, then enter it quantitatively in a $50 \mathrm{ml}$ graduate flask. Added methanol: distilled water $(1: 4)$ then homogenized stirred and added solvents to the sign-line, and filtered, it's called test solution. Pipette $5 \mathrm{ml}$ of the test solution and put into a $25 \mathrm{ml}$ graduated flask, added solvent 
RASĀYAN J. Chem.

Vol. 13 | No. 4 |2256-2265| October - December | 2020

to the sign- line, measured absorption at a wavelength of $200-400 \mathrm{~nm}$, the absorbance ratio value is sought. ${ }^{8,15}$

\section{Statistical Data Analysis}

The test used in this study is the t-test. Data distribution is calculated using a formula. ${ }^{23,24}$

$$
\mathrm{t}_{\text {count }}=\left|\frac{\mathrm{X}-\overline{\mathrm{X}}}{\mathrm{SD} / \sqrt{\mathrm{n}}}\right|
$$

The actual level with a $99 \%$ confidence level is calculated using the formula: ${ }^{23,24}$

$$
\mu=\bar{X} \pm t_{\left(1-\frac{1}{2} \alpha\right) \mathrm{dk}} \times \frac{\mathrm{SD}}{\sqrt{\mathrm{n}}}
$$

Note:

$\mu=$ actual level interval

$\mathrm{X}^{-}=$the average level of the sample

$\mathrm{X}=$ sample level

$\mathrm{t}=$ price $\mathrm{t}$ table according to $\mathrm{dk}=\mathrm{n}-1$

$\mathrm{dk}=$ degree of freedom $(\mathrm{n}-1)$

$\alpha=$ level of trust

$\mathrm{SD}=$ standard deviation

$\mathrm{N}=$ number of replications

\section{Constructing Result of Curve Absorption Spectrum}

The determination curve absorption spectrum each using an action solution of $36.4 \mu \mathrm{g} / \mathrm{ml} \mathrm{GUA}$, six $\mu \mathrm{g} / \mathrm{ml}$ ACET, and $31.3 \mu \mathrm{g} / \mathrm{ml} \mathrm{CTM} .^{6}$ The result showed in Fig.- 1 . The curve of the spectrum absorption from GUA, ACET, CTM respectively, and its combination (Fig.-1) and Its overlapped (Fig.-2).

This study used methanol-water solvents with a ratio of 4: 1 and obtained maximum absorption from GUA at a wavelength of $273.2 \mathrm{~nm}$ while in acidic solutions had a maximum wavelength of around $273 \mathrm{~nm}$, because in $\mathrm{pH}$ under acidic conditions, there was no change in maximum wavelength. ACET has maximum absorption in $257 \mathrm{~nm}$ alkaline solvent and becomes wavelength $244.4 \mathrm{~nm}$ in methanol-water, and CTM at $262 \mathrm{~nm}$ wavelength in alkaline solvent and with methanol: water is the solvents to $261.4 \mathrm{~nm}$, because the solvents used is different from solvents in the literature. ${ }^{5,6}$

The Fig.-2 shows that the simple ultraviolet spectrophotometric method is difficult to use to establish a mixture of GUA, ACET, and CTM simultaneously. Because the spectrum of three substances overlap each other, so it does not describe the concentration of the content in these substances in the mixture. Then the ultraviolet spectrophotometry method improves of ratio spectra of mean centralization and the absorption ratio, which makes it possible to set the concentration of each simultaneously without separation. ${ }^{8,15}$

\section{The Ratio Spectra of Mean Centralization Method}

Method of Validation parameter is an exact data, nicety, the threshold of detection (LOD), and quantitation threshold (LOQ). Exact data are stated by a percentage of recovery determined by the standard addition method. The validation test of percentage recovery has used a sample of local product syrup. The requirement for recovery level is $98-102 \%$, and the average level of recovery in syrup is $100.06 \%$ for ACET, $100.03 \%$ for GUA, and $99.83 \%$ for CTM. The relative standard deviation meets the requirements with an RSD value of less than $2 \%$, namely $1.03 \%$ for ACET, $0.95 \%$ for GUA, and $1.58 \%$ for CTM. The threshold of detection and quantitation of threshold is $0.1043 \mu \mathrm{g} / \mathrm{ml}$ and $0.3478 \mu \mathrm{g} / \mathrm{ml}$ for ACET, $0.7914 \mu \mathrm{g} / \mathrm{ml}$ and $2.6380 \mu \mathrm{g} / \mathrm{ml}$ for GUA and for CTM respectively are $1.4744 \mu \mathrm{g} / \mathrm{ml}$ and $4.9146 \mu \mathrm{g} / \mathrm{ml}$ (Table-1). So that, the mixture analysis of GUA, ACET, and CTM with Mean Centralization of Ratio Spectra has met the method validation requirements. ${ }^{21,22}$

\section{The Mean Center with a Second Ratio}

The mean center (MC) of the first spectrum ratio GUA is made at a wavelength of $220-280 \mathrm{~nm}$. The vector is divided by the MC ratio value of $9 \mu \mathrm{g} / \mathrm{ml}$ ACET and $41 \mu \mathrm{g} / \mathrm{ml} \mathrm{CTM}$, so that the second spectrum ratio of GUA is obtained. At the same time, the ACET used the MC ratio value of $44 \mu \mathrm{g} / \mathrm{ml} \mathrm{GUA}$ and $41 \mu \mathrm{g} / \mathrm{ml}$ CTM. The CTM is divided by the MC ratio value of $9 \mu \mathrm{g} / \mathrm{ml} \mathrm{ACET} \mathrm{and} 52 \mu \mathrm{g} / \mathrm{ml}$ GUA. 
RASĀYAN J. Chem.

Vol. 13 | No. 4 |2256-2265| October - December | 2020

The absorbance spectrum data of each standard are analyzed divided by the dividing factor and has been determined using the software UV Probe 2.42. So that the absorbance ratio results are obtained. Construction of the absorption spectrum by ratio spectra of mean centralization (MCR) is a continuation of the second spectrum ratio input into the MATLAB software and looking for the MC value of each spectrum $^{8-10}$. The absorbance of each drug is no longer affected by the other components so that the absorbance of each spectrum has expressed the absorbance of the drug itself (Fig.-3).
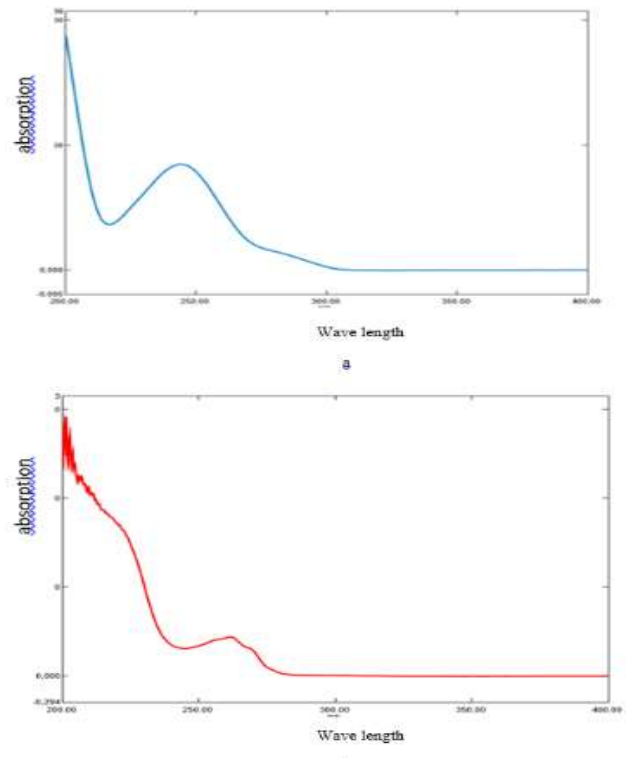

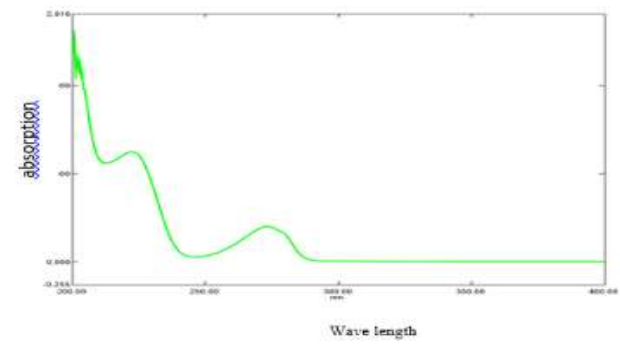

b

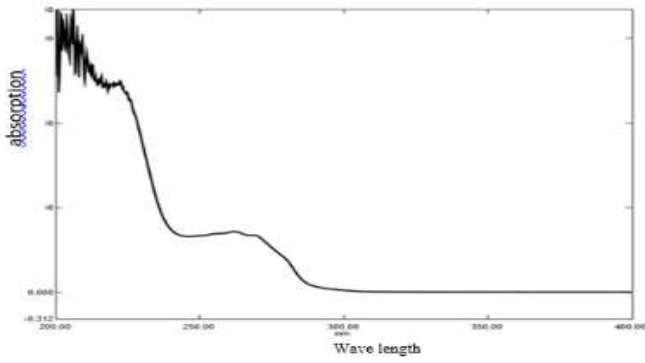

a

Fig.-1: The Absorption Spectrum of a. GUA, b. ACET, c. CTM, d. GUA, ACET, and CTM Mixture

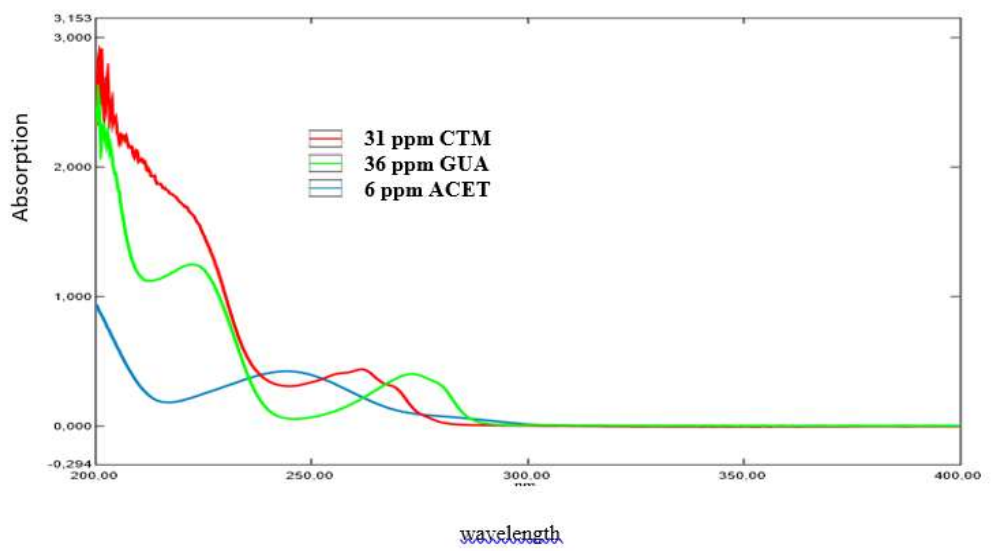

Fig.-2: Overlapped of GUA, ACET and CTM Spectrum Absorption

Table-1: Analysis of Validation Parameters for GUA, ACET, and CTM

\begin{tabular}{c|c|c|c}
\hline Parameter & ACET & GUA & CTM \\
\hline Exact data $(\%)$ & 100.06 & 100.03 & 99.83 \\
\hline Nicety $(\%)$ & 1.0326 & 0.9597 & 1.5807 \\
\hline Linearity $(\%)$ & 1.0320 & 0.9594 & 1.5834 \\
\hline LOD $(\mu \mathrm{g} / \mathrm{ml})$ & 0.1043 & 0.7914 & 1.4744 \\
\hline LOQ $(\mu \mathrm{g} / \mathrm{ml})$ & 0.3478 & 2.6380 & 4.9146 \\
\hline
\end{tabular}

Measurement of amplitude at $274 \mathrm{~nm}$ was used for determination of the GUA level, which corresponds to the maximum wavelength in MC of the spectrum of the two GUA ratios. Determination of ACET levels at 
RASĀYAN J. Chem.

Vol. 13 | No. 4 |2256-2265| October - December | 2020

$269 \mathrm{~nm}, \mathrm{CTM}$ at $257 \mathrm{~nm}$. The same procedure was used after addition to the GUA and CTM samples to connect the legal requirements of Lambert-Beer. ${ }^{8-10}$ The results of the MC value of each component in the local product syrup (Fig.-4).
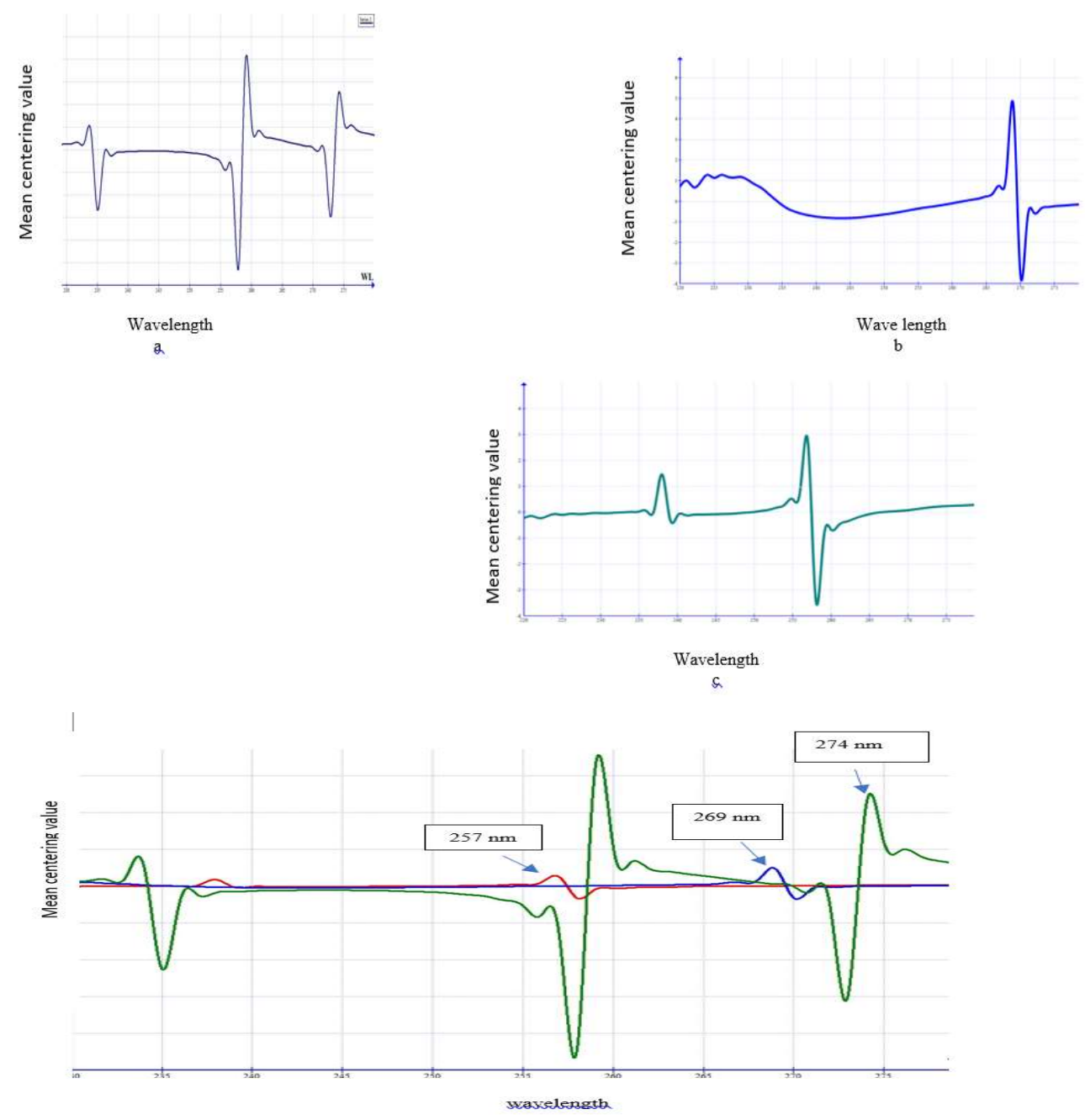

d.

Fig.-3: Curve of Mean Center Value Versus Wavelength of a. GUA, b. ACET, c. CTM and d. Mixture of GUA,

\section{The Calibration Curve of MCR Method} ACET and CTM

The regression equation and correlation coefficient are calculated, the regression equation for GUA is obtained, namely $\mathrm{y}=0.6017 \mathrm{x}-0.0579$ with $\mathrm{r} 2$ value $=0.9999$, and ACET is $\mathrm{y}=0.73291 \mathrm{x}+0.0043$ with $\mathrm{r} 2=0.9999$, while CTM is $\mathrm{y}=0.0075 \mathrm{x}+0.0015$ with the price of $\mathrm{r} 2=0.9997$. The value of $\mathrm{r}$ count $\leq 1$ indicates a good linearity. ${ }^{23,24}$

\section{The Ratio of Absorbance Method}

The ratio of absorbance method is used at two selected wavelengths, where one wavelength is an isoabsorptive point, and the other is the maximum wavelength of one of the substances. This method begins with the determination of the iso-absorptive point by attaching the spectrum absorption curve of three materials (Fig.-5). The intersection of the three curves is called the ISO-absorptive point. ${ }^{15-17}$

The Fig.-5 shows that the GUA, ACET and CTM have an ISO-absorptive point, at a wavelength of 235.8 $\mathrm{nm}$. These studies, conduct that the wavelength of the selected drugs is $244.4 \mathrm{~nm}$, which is the wavelength of ACET. 
RASĀYAN J. Chem.

Vol. 13 | No. 4 |2256-2265| October - December | 2020
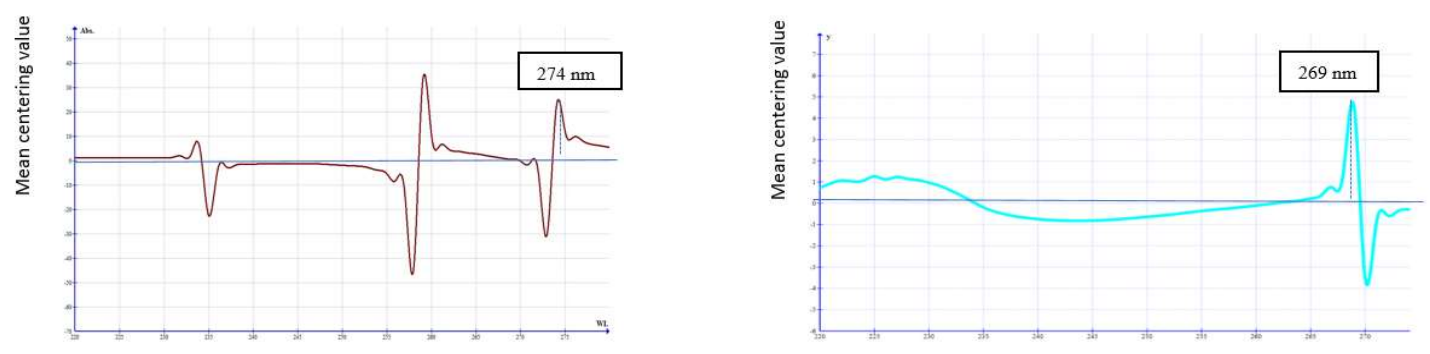

Wavelength
a.

Wavelength
b.

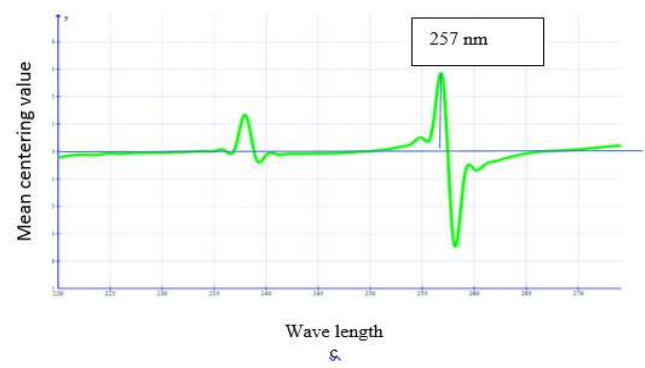

Fig.-4: Curve of Mean Center Value Versus Wavelength of a. GUA, b. ACET, c. CTM from Local Product Syrup

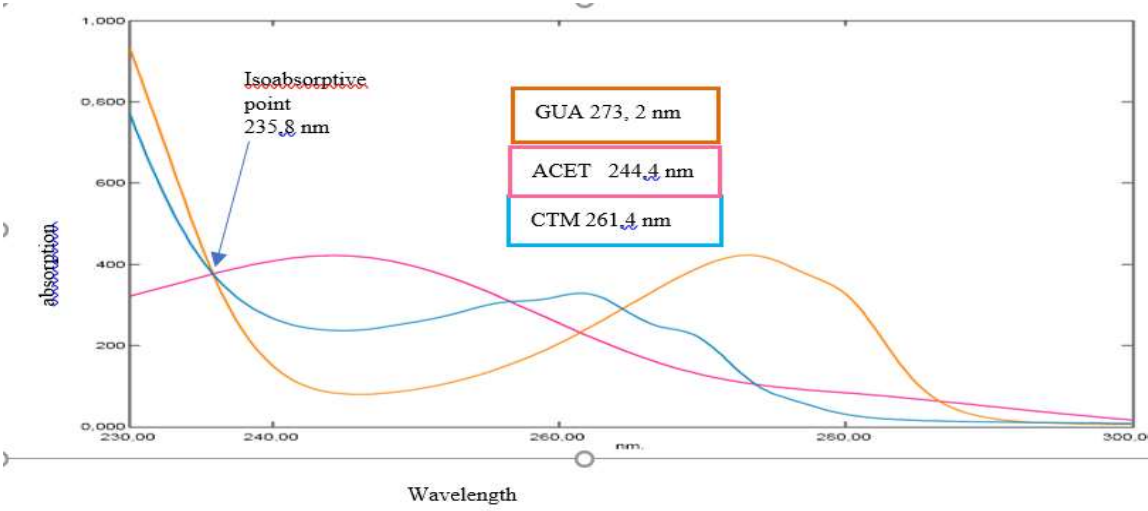

Fig.-5:Overlapping spectra absorption of the GUA, ACET and CTM

Validation of Absorption of Ratio Methods

The validation parameters tested were exact data, nicety, threshold of detection (LOD), and quantitation threshold (LOQ). The exact data tests are expressed in percentage recovery determined by the standard addition method. ${ }^{21,22}$ The validation tests were carried out with a standard addition method in syrup samples (Table- 2).

Table-2: Analysis and Summary Data of Validation Parameters for GUA, ACET, and CTM

\begin{tabular}{c|c|c|c|c|c|c}
\hline Parameter & \multicolumn{2}{|c|}{ ACET } & \multicolumn{2}{c|}{ GUA } & \multicolumn{2}{c}{ CTM } \\
\hline Wavelength $(\mathrm{nm})$ & 244.4 & 235.8 & 273.2 & 235.8 & 261.4 & 235.8 \\
\hline $\begin{array}{c}\text { Concentration }(\mu \mathrm{g} / \\
\mathrm{ml})\end{array}$ & $3-9$ & $3-9$ & $20.2-52.6$ & $20.2-52.6$ & $21.3-41$ & $21.3-41$ \\
\hline $\begin{array}{c}\text { Regression } \\
\text { equation }\end{array}$ & $\begin{array}{c}0.07021 \mathrm{x}+ \\
0.00101\end{array}$ & $\begin{array}{c}0.5397 \mathrm{x}- \\
4.7798\end{array}$ & $\begin{array}{c}0.01109 \mathrm{x}+ \\
0.00204\end{array}$ & $\begin{array}{c}0.1050 \mathrm{x}- \\
3.4351\end{array}$ & $\begin{array}{c}0.01412 \mathrm{x}+ \\
0.00210\end{array}$ & $\begin{array}{c}0.3175 \mathrm{x}- \\
9.3511\end{array}$ \\
\hline Slope (a) & 0.07021 & 0.5397 & 0.01109 & 0.1050 & 0.01412 & 0.3175 \\
\hline Intercept (b) & 0.00101 & -4.7798 & 0.00204 & -3.4351 & 0.00210 & -9.3511 \\
\hline $\begin{array}{c}\text { Coefficient } \\
\text { correlation }\left(\mathrm{r}^{2}\right)\end{array}$ & 0.9998 & 0.9997 & 0.9999 & 0.9996 & 0.9999 & 0.9995 \\
\hline
\end{tabular}


RASĀYAN J. Chem.

Vol. 13 | No. 4 |2256-2265| October - December | 2020

\begin{tabular}{c|c|c|c}
\hline LOD $(\mu \mathrm{g} / \mathrm{ml})$ & 0.0405 & 0.2231 & 0.0962 \\
\hline LOQ $\mu \mathrm{g} / \mathrm{ml})$ & 0.1220 & 0.6761 & 0.2916 \\
\hline RSD $(\%)$ & 0.20 & 0.33 & 0.05 \\
\hline
\end{tabular}

The Table- 1 and Table- 2 shows that after exact data testing is done by three sample concentration calculation with a specific range of $80 \%, 100 \%, 120 \%$ calculated from equality, it can be said that this recovery test meets the predetermined accuracy requirements. The exact data expressed by recovery values for drug compounds in a mixture is approximately $98 \%-102 \%$ If the average yield is in that range, then all of the percent of recovery shows good accuracy at the time of treatment of GUA, ACET and CTM levels. ${ }^{21}$, ${ }^{22}$ Linearity is the ability of analytical methods that respond with the precision or the help of mathematical calculation transformations, which comparable to the condition of analytes in the sample as a parameter, there is a linear relationship used correlation coefficient in regression analysis. ${ }^{23-24}$ The Calibration curve can show the following (Fig.-6).

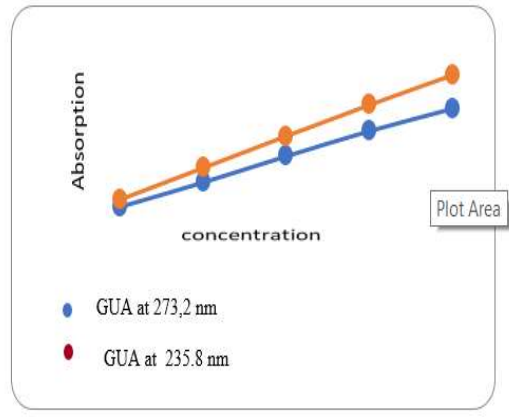

a.

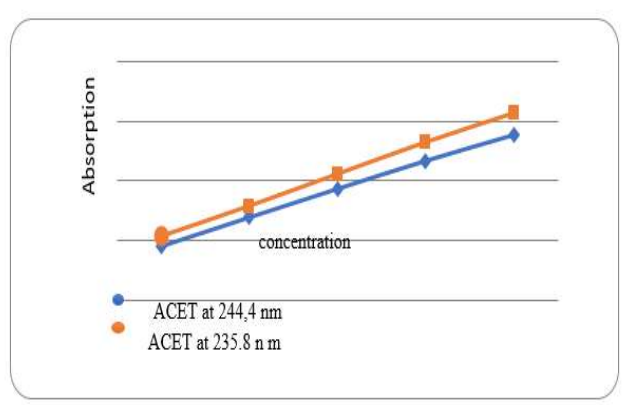

b.

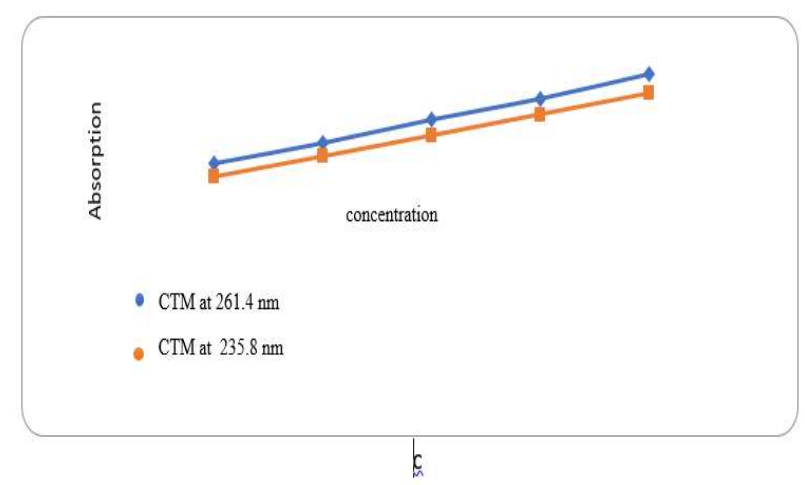

Fig.-6: Calibration Curve a. GUA at $273.2 \mathrm{~nm} ; 235.8 \mathrm{~nm}$, b. ACET at $244.4 \mathrm{~nm}, 235.8 \mathrm{~nm}$, and c. CTM at 261.4 $\mathrm{nm}$ and $235.8 \mathrm{~nm}$

Based on Fig.- 6 of the three equations is obtained, that the connection between the concentration and absorption is linear. The correlation coefficient from ACET is 0.9998 and 0.9997 at wavelengths $244.4 \mathrm{~nm}$ and 235.8 respectively, GUA is 0.9999 and 0.9996 at wavelength $273.2 \mathrm{~nm}$ and $235.8 \mathrm{~nm}$, respectively, and CTM is 0.9999 and 0.9995 at wavelengths of $261.4 \mathrm{~nm}$ and 235.8 respectively. The relationship of ideal linear is achieved depends on the value $b=0$ and are $=+1$ or -1 on the direction of the regression line. While the value of a show sensitivity analysis, especially the instruments. ${ }^{19,20}$ The that results obtained in the sample measurements were above the detection limit and the limit of quantitation The concentration contained in the quantitation limit or LOQ is the minimum concentration that must be measured in a sample so that quantitative absorbance readings. ${ }^{21-22}$ 
RASĀYAN J. Chem.

Vol. 13 | No. 4 |2256-2265| October - December | 2020

The Determination Result of Component Levels in Syrup Preparations

The absorption of GUA and CTM in syrup does not meet the Lambert-Beer law. So that the addition of GUA was $34.8 \mu \mathrm{g} / \mathrm{ml}$, and CTM is added $30.96 \mu \mathrm{g} / \mathrm{ml}$. According to Harmita (2004), in the addition method, several samples were analyzed plus analysts with the required levels of the analyst content, which was estimated, mixed, and explained, again. The three components of this drug and their replications have levels that meet the requirements of USP XXX, then proceed with the T-test, the results of the levels are obtained (Table- 3 ). ${ }^{5,24}$

Table-3: Statistical Results of the Three Components in Local Product Syrup

\begin{tabular}{c|c|c|c|c}
\hline \multicolumn{5}{c}{ Mean Centralization of Ratio Spectra Method } \\
\hline No & Component & Level Percentage(\%) & $\begin{array}{c}\text { Etiquette Content } \\
(\mathrm{mg} / 5 \mathrm{ml})\end{array}$ & Level Requirements (\%) \\
\hline 1. & GUA & $(100,85 \pm 0,78)$ & $25 \mathrm{mg}$ & $90-110$ \\
\hline 2 & ACET & $(100,76 \pm 1,42)$ & $120 \mathrm{mg}$ & $90-110$ \\
\hline 3 & CTM & $(101,43 \pm 0,53)$ & $1 \mathrm{mg}$ & $90-110$ \\
\hline \multicolumn{5}{|c|}{ Absorption of Ratio Methods } \\
\hline 1 & GUA & $(99.16 \pm 0.014) \%$ & $25 \mathrm{mg}$ & Level requirements (\%) \\
\hline 2 & ACET & $(99.77 \pm 0.014) \%$ & $120 \mathrm{mg}$ & $90-110$ \\
\hline 3 & CTM & $(99.71 \pm 0.014) \%$ & $1 \mathrm{mg}$ & $90-110$ \\
\hline
\end{tabular}

Based on Table- 3 show that the range of mean values of GUA, ACET, and CTM mixture with the Mean centralization of the ratio spectrum method and the method of ratio absorption using stock addition of twocomponent have a great validation. And the levels of each component of this syrup have been suitable with the standards listed in USP XXX, and this means that the content of GUA, ACET, and CTM content in these preparations have appropriate levels with their use as anti-influenza drugs, and cough. ${ }^{5}$

\section{CONCLUSION}

The conclusion of a research that syrup preparation containing GUA, ACET, and CTM in their local production preparations of USP XXX ${ }^{5}$. Their composition is cough and influenza drugs over the counter market. This combination is one of the fixed-dose combinations of flu drugs that contain analgesics, antihistamines, and antitussives. The dosage of the three active ingredients in the fixed combination of flu drugs was still within the recommended dosage limit in the pharmacopeia.

\section{ACKNOWLEDGEMENT}

1. Thank you to the Chancellor of the Universitas Sumatera Utara and Chairman of the USU Research Institute, for his approval of the research of my professor at the Universitas Sumatera Utara, through the professor's research program in the Talent research program in 2019 with the number 16 / UN5. 2.3.1 / PPM / KP / TALENTA USU. 2019.

2. The author wishes to thank Retno Priscillia Silalahi and Febryanto wiranata saragih, the student of undergraduate at the Department of Chemistry, Faculty of Pharmacy, Universitas Sumatera Utara for all contributions on technical help to the work reported in this manuscript.

\section{REFERENCES}

1. G. A. Goodman, J. G. Hardman, and L. E. Limbird, 2006, Goodman and Gilman's The Pharmacological Basis of Therapeutics, $10^{\text {th }}$ Ed, The McGraw-Hill Companies, Inc, Medical Publishing Division, p.117, DOI:10.1036/0071422803

2. T.H.Tjay, and K Rahardja, 2002, Essential Medicines for Efficacy, Use, and Side Effects, Fifth edition. Jakarta: Elex Media Komputindo, p.773

3. P.R.Shankar, P. Partha, and Shenoy, BMC Family Practice, 3,17(2002), DOI:10.1186/1471-2296$3-17$ 
RASĀYAN J. Chem.

Vol. 13 | No. 4 |2256-2265| October - December | 2020

4. Indonesian Pharmacopoeia, 2014, Fifth Edition, Jakarta, Ministry of Health of the Republic of Indonesia, p. 498, 848, 1077.

5. The United States Pharmacopeia, 1989, USP 30, The National Formulary, NF XXII, Rockville, MD: U.S Pharmacopeial Convention, Inc, p. 1293.

6. J. Cordonnier and J. Schaep, 2011, Ultraviolet, Visible and Fluorescence Spectrophotometry, In: A.C.Moffat, M.D. Osselton, B.Widdop, and L.Y.Galichet, Clarke's Analysis of Drugs and Poisons, $4^{\text {th }}$ ed, London, Pharmaceutical Press, p. 1087, 1468, 1856.

7. Muchlisyam and T.R.Pardede, 2017, Spectrophotometry and Multicomponent Drug Analysis, Medan: USU Press, p. 19-21, 26, 98-100.

8. A.Afkhami and M.Bahram, Talanta, 66(3), 712(2005), DOI:10.1016/j.talanta. 2004. 12.004

9. H.W. Darwish, S.A. Hassan, M.Y.Salem and B.A. El-Zeiny, Spectrochimica Acta Part A: Molecular and Biomolecular Spectroscopy, 83(1), 140(2011), DOI: 10.1016/j.saaa.2011.08.005

10. N.M. Bhatt, V.D. Chavada, M. Sanyal, and P.S. Shrivastav, The Scientific World Journal, 2014, 495739, (2014), DOI: 10.1155/2014/495739

11. N.S. Abdelwahab, W.A. Nouruddin, H.M.E.L. Fatatry, and W.M. Osman, Journal of Chromatography Separation Technique, 4(8),1(2013), DOI:10.4172/2157-7064.100019

12. M.M.Abdelrahman, and E.A. Abdelaleem, Journal of Saudi Chemical Society-Elsevier, 20(S1), S153(2016), DOI:10.1016/j.jscs.2012.10.003

13. B. Muchlisyam and S.Exaudia, Rasayan Journal of Chemistry, 12(3), 1509(2019), DOI:10.31788 / RJC.2019.1235208

14. Muchlisyam, E.S.B. Raesa, R. Dathita and S.P. Richa, Rasayan Journal of Chemistry, 12(4), 1693(2019), DOI: 10.31788/RJC.2019.1245428

15. B. Muchlisyam, R.Julia, P.Yade Metri and C. E. A. Situmorang, Rasayan Journal of Chemistry, 12(1),232(2019), DOI: 10.31788.RJC.2019.1215013

16. H. Padh, S.Parmar, and B. Patel, International Journal of Pharmaceutical Sciences and Research, 9(8), 3355(2018), DOI:10.13040/IJPSR.0975-8232.9(8).3355-59

17. M. Attimarad, V.K.Narayanswamy, B.E.Aldhubaib, N. SreeHarsha and A.B.Nair. PLOS ONE, 14(9), e0222526 (2019), DOI:10.1371/journal.pone.0222526

18. A.Rohman, 2007, Pharmaceutical Chemistry Analysis, First print, Yogyakarta: Student Library, p. 220-262.

19. K. Satiadarma, M. Mulja, D.H.Tjahjono and R.E.Kartasasmita, 2004, Principles of Development of Analysis Procedures, First edition, Surabaya, Airlangga University Press, p.46-47, 49, 92.

20. I.G.Gandjar and A. Rohman, 2012, Drug Analysis by Spectrophotometry and Chromatography, First edition, Yogyakarta: Pustaka Pelajar, p. 59-110.

21. J. Ermer and J. H. Miller, 2005, Method Validation in Pharmaceutical Analysis. A Guide to Best Practice. Weinheim: Wiley-Vch Verlag GmBH \& Co. KGaA, 171.

22. Harmita, Pharmaceutical Science Magazine, 3(1), 117(2004), DOI: 10.7454/ psr.v1i3.3375

23. M.Mulja and Suharman, 1995, Instrument Analysis, Surabaya, Airlangga University Press, p.1-59.

24 Sudjana, 2005, Statistics Method, Sixth Edition, Third Reprint, Bandung: Tarsito, Publisher, p.168.

[RJC-5790/2020] 